\title{
Histometric Study of Alveolar Bone in Rats Submitted to Ethanol During Lactation
}

\author{
Estudio Histométrico del Hueso Alveolar en Ratas Sometidas a Etanol Durante la Lactancia \\ ${ }^{*, * *}$ Viviane Curi ; "Reinaldo Azoubel; ${ }^{* * *, * * * * *}$ Ruberval Armando Lopes; \\ ${ }^{*, * *, * * * * * *}$ Alex Tadeu Martins; ${ }^{* * * * *}$ Miguel Angel Sala Di Matteo \& ${ }^{*, * *}$ Elias Naim Kassis
}

CURI, V.; AZOUBEL, R.; LOPES, R. A.; MARTINS, A. T.; DI MATTEO, M. A. S. \& KASSIS, E. N. Histometric study of alveolar bone in rats submitted to ethanol during lactation. Int. J. Morphol., 26(4):945-950, 2008.

SUMMARY: The present work studied the adverse effects of maternal exposure of rats to alcohol during lactation, on the development of their offspring. Histometric evaluation by karyometry and of the alveolar bone at the level of the first upper molar of the sucking was perfomed. Two groups of animals, one coming from mothers exposed to drinking water containing $20 \%$ ethanol during the total lactation period and the other of controls coming from mothers receiving only alcohol-free drinking water during this period. On the 21 first day of lactation the young of each group were aleatorily selected and following anesthesia, their heads severed; after histological treatment, serial $6 \mu \mathrm{m}$ sections on the frontal plane at the molar level, stained with hematoxilin and eosin, were obtained. The experimental results produced, suggest that sucking from ethanol-treated mothers, show retarded post-natal growth, their alveolar bones presenting scarce, little calcified trabeculae, and a more abundant bone marrow compared to controls.

KEY WORDS: Ethanol; Alveolar bone; Lactation.

\section{INTRODUCTION}

In Latin America, consumption of alcoholic beverages by the feminine sex has been increasing dramatically over the last twenty years (Veazie \& Smith, 2000), being considered one of its most serious public health problems. Complications at somatic and psychic levels, besides profound repercussion on the social environment are involved (Faustino \& Stipp, 2003).

In Brazil, preliminary data raised by the Federal University of São Paulo, verified a $6.6 \%$ prevalence of alcoholism in the population of 24 counties of the State of $S$. Paulo, with male predominance, but of $19.16 \%$ of the female population (Burgos et al., 2004).

In women, compared to men, alcohol reaches higher concentrations in the blood, and is absorbed in higher amounts due to the larger amount of their body fat and lesser amount of body liquid. Therefore, it is more harmful in women of similar corporal mass. These consumption patterns refer to non-pregnant women; in this condition, total abstinence from alcohol is recommended (Hochgraf et al., 1995).

During pregnancy, alcohol may cause serious physical and mental deficiencies in the fetus, as well as a predisposition for its consumption in adults (Grant, 1997). Drinking during pregnancy is the major known cause of congenital anomalies. Fetal alcohol syndrome, one of the major consequences of its utilization during that period, occurs in about 2.2 of every 1000 living newborn, accounting for a specific pattern of congenital malformations that include delayed pre-and postnatal growth, face dimorphism, ptosis, strabismus, short lip fissures, member anomalies, nervous system dysfunction (Clarren \& Smith, 1978); microcephaly, cardiac defects (Jones et al., 1973; Jones \& Smith, 1975; Hanson et al., 1976; Peiffer et al., 1979), and of neural tube (Goldstein \& Arulanantham, 1978) and renal anomalies (DeBeukelaer et al., 1977; Goldstein \& Arulanantham; Pfeiffer et al.)

\footnotetext{
School of Medicine at São José Do Rio Preto - FAMERP, Brasil.

** Post Graduation Program - School of Dentistry at São José Do Rio Preto - UNORP, Brasil.

*** Stomatology Department of the Faculty of Odontology of the Ribeirão Preto - USP, Brasil.

${ }^{* * * * *}$ School of Dentistry of Franca - UNIFRAN, Brasil.

${ }^{* * * * * *}$ Professor of School of Dentistry of Barretos- FEB, Brasil.

Financial Support UNIFRAN, Brasil.
} 
Since 1983, according to Mennella \& Beauchamp (1993), alcohol has been considered a drug that following ingestion, passes into maternal milk demanding its abolition during the whole lactation period. An alert has been made about the precautions necessary concerning the potential of the exposure to alcohol excreted in mother milk: in special since studies by Little et al. (1989), evidenced that alcoholic mothers do not modify their habit of its consuming alcoholic beverages during lactation.

The chronic exposure to ethanol during the lactation period, induces significant metabolic disturbances in mothers, that include alterations in mammary gland function leading to decreased total milk production, and of milk having an increased lipid content (Vilaró et al., 1987). Its continuous ingestion during this phase, alters milk chemical composition (Sanchis \& Guerri, 1986; Viñas et al., 1987) resulting in the appearance of ethanol and acetaldehyde (Sanchis \& Guerri) and exacerbating ethanol effects on the newborn (Guerri et al., 1984).

Do Carmo et al. (1999) observed that maternal alcohol ingestion decreases milk production, leading to serious malnutrition in the rat offspring, partly compensated by the increased lipid content of milk that leads to metabolic adaptations preventing severe hypoglycemia and maintenance of minimal levels of hepatic glycogen.

Keeping in mind that lactation is an important, vulnerable period and that maternal exposure to alcohol during this phase, may lead to adverse effects to the developing offspring, it is the aim of this work to histometrically (by karyometry and stereology), evaluate the alveolar bone at the level of the first upper molar of the young rats that had been submitted to the effects of ethanol during lactation.

\section{MATERIAL AND METHOD}

Ten female albino Wistar rats, weighing on an average $200 \mathrm{~g}$, together with 80 cubs from various litters, were placed in individual cages receiving solid food and water $a d$ libitum. They were aleatorily divided into two groups:

Group 1 was made up of 5 rats that received 20\% ethanol in their drinking water, during the whole lactation period (21 days), plus 8 young; group 2, contained the same number of rats, but only water in their drinking vessels during an identical period of time.

On the $21^{\text {st }}$ day of lactation, 5 young from each group were aleatorily selected making up the treated and controls of this study, respectively. They were weighted on a precision balance and sacrificed by an anesthetic overdose (injection of 3\% Hypnold).

The heads of the young were separated from their bodies and following histological treatment, serial $6 \mu \mathrm{m}$ slices starting at the frontal plane at the molars, dyed with hematoxylin-eosin.

For histometry, 50 nuclei of osteoblasts and 50 osteocytes of each selected animal, were evaluated with an optical microscope with camera lucida (Nikon), and a 1000fold final magnification; elliptical structures were contoured on white sulfite paper with a black, number 2 pencil. Following the determination of the major (D) and minor (d) diameters with a millimeter ruler, the karyometric parameters: mean geometric diameter, ratios between longest to shortest axis, perimeters, areas, volumes, volume to area ratios, eccentricity, shape factor and contours indexes, were obtained (Sala et al., 1994).

The same material was submitted to stereology, by means of an optical microscope with a camera lucida and a preconized Merz (1967) grid application A projection of 20 different fields of 100 points each, totaling 2000 points for each component of the groups was performed. By this technique, the following parameters could be obtained: cytoplasmic volumes, cell volumes, ratios of nucleus to cytoplasm, and numerical cell density (Delesse, 1848; Chalkley, 1943; Tomkeieff, 1945; Weibel, 1969; Sala et al.; 1992).

For statistical comparisons between the morphometric results from treated and control groups respectively, the nonparametric Wilcoxon-Mann-Whitney test was utilized.

\section{RESULTS}

Table I shows the comparison and the statistical analysis between the young of control (C) and ethanol treated (T) rats.

This Table permits the recognition of the statistically significant reduction of the body weights of the group of treated animals.

Table I. Mean values of body weights ( $\mathrm{g}$ ), of control and ethanol treated animals using the Wilcoxon-Mann- Whitney test for statistical comparisons.

\begin{tabular}{ccccc}
\hline Parameter & Control & Treat ed & $\mathbf{U}$ & $\mathbf{p}[\mathbf{U}]$ \\
\hline Body weight & $34.86 \mathrm{~g}$ & $20.20 \mathrm{~g}$ & $0 *$ & 0.004 \\
\hline
\end{tabular}


Table II shows the statistical analysis of the comparison between the osteoblasts of control $(\mathrm{C})$ and ethanol treated $(\mathrm{T})$ rats.

It can be observed that of all the karyometric parameters presented, the ten which were statistically different from the control group were: major, minor and mean diameters $(\mu \mathrm{m})$, major-minor diameter ratio, volume $(\mu \mathrm{m} 3)$, area $\left(\mu \mathrm{m}^{2}\right)$, perimeter $(\mu \mathrm{m})$ and the volume-area ratio, eccentricity and contour index. Conversely, the only data that did not show statistically significant differences were those of the shape factor.

Table II. Mean values for major, minor and mean diameters $(\mu \mathrm{m})$, ratio between major and minor diameter, volume $\left(\mu \mathrm{m}^{3}\right)$. area $\left(\mu \mathrm{m}^{2}\right)$, perimeter $(\mu \mathrm{m})$, volume-area ratio, eccentricity, shape factor and contour index for osteoblasts nuclei of control (C) and ethanol treated animals (T). Wilcoxon-Mann-Whitney test.

\begin{tabular}{lcccc}
\hline \multicolumn{1}{c}{ Parameter } & Control & Treat ed & $\mathbf{U}$ & $\mathbf{p}[\mathbf{U}]$ \\
\hline Major diameter & 6.81 & 5.42 & $3^{* *}$ & 0.028 \\
Minor diameter & 3.81 & 3.28 & $1^{*}$ & 0.008 \\
Mean diameter & 5.05 & 4.19 & $3^{* *}$ & 0.028 \\
Major-minor diameter ratio & 1.88 & 1.69 & $3^{* *}$ & 0.028 \\
Volume & 70.76 & 43.77 & $3^{* *}$ & 0.028 \\
Area & 20.37 & 14.46 & $2^{* *}$ & 0.016 \\
Perimeter & 17.08 & 13.97 & $2^{* *}$ & 0.016 \\
Volume-area ratio & 3.36 & 2.79 & $2^{* *}$ & 0.016 \\
Eccentricity & 0.79 & 0.72 & $3^{* *}$ & 0.028 \\
Shape factor & 0.87 & 0.88 & $12^{\text {ns }}$ & 0.500 \\
Contour index & 3.83 & 3.74 & $3^{* *}$ & 0.028 \\
\hline
\end{tabular}

In Table III, mean differences in nuclear parameters of osteocytes are demonstrated for control (C) and treated (T) groups as well as the statistical analysis.

Table III. Mean values for major, minor and mean diameter $(\mu \mathrm{m})$, and their ratio, volume $\left(\mu \mathrm{m}^{3}\right)$. area $\left(\mu \mathrm{m}^{2}\right)$. perimeter $(\mu \mathrm{m})$, volume-area ratio, eccentricity, shape factor and contour index for osteocytes nuclei of control (C) and ethanol treated animals (T). Wilcoxon-Mann-Whitney test.

\begin{tabular}{lcccc}
\hline \multicolumn{1}{c}{ Parameter } & Control & Treated & $\mathbf{U}$ & $\mathbf{p}[\mathbf{U}]$ \\
\hline Major diameter & 6.50 & 5.04 & $0^{*}$ & 0.004 \\
Minor diameter & 5.25 & 3.82 & $0^{*}$ & 0.004 \\
Mean diameter & 5.82 & 4.37 & $0^{*}$ & 0.004 \\
Major-minor diameter ratio & 1.26 & 1.34 & $6^{\mathrm{ns}}$ & 0.111 \\
Volume & 110.14 & 47.54 & $0^{*}$ & 0.004 \\
Area & 27.19 & 15.44 & $0^{*}$ & 0.004 \\
Perimeter & 18.54 & 14.02 & $0^{*}$ & 0.004 \\
Volume-area ratio & 3.88 & 2.91 & $0^{*}$ & 0.004 \\
Eccentricity & 0.49 & 0.54 & $8^{\mathrm{ns}}$ & 0.210 \\
Shape factor & 0.98 & 0.96 & $5^{\mathrm{ns}}$ & 0.075 \\
Contour index & 3.59 & 3.62 & $5^{\mathrm{ns}}$ & 0.075 \\
\hline
\end{tabular}

It can be observed that, of all the karyometric parameters presented, the seven which were statistically different from the control group were: major, minor and mean diameters $(\mu \mathrm{m})$, volume $\left(\mu \mathrm{m}^{3}\right)$, area $\left(\mu \mathrm{m}^{2}\right)$, perimeter $(\mu \mathrm{m})$ and volume-area ratio. The four that did not show statistically significant differences were: major-minor diameter ratios, eccentricity, shape factor and contour index.

Table IV demonstrates stereological parameters detected in this experiment.

The stereological analysis of the osteocytes of the young of control (C) and ethanol treated rats $(\mathrm{T})$, respectively, demonstrated on Table IV, reveal that the cytoplasm volume $\left(\mu \mathrm{m}^{3}\right)$, the cell volume $\left(\mu \mathrm{m}^{3}\right)$ and the numerical cell density ( $\mathrm{n}^{\circ} \mathrm{of}$ cells $/ \mu \mathrm{m}^{3}$ ) presented statistically significant differences in the comparison between the groups, in contrast to the relation nucleus/ cytoplasm when the Wilcoxon-MannWhitney test was applied.

Table $\mathrm{V}$ demonstrates the percent mean values of the structure of the alveolar bone of animals belonging to the control and treated groups, respectively.

It can be detected from the table, that treated animals - exempting the bone medula, that presented a percentage value higher than the controls - bone parameters were reduced when statistically compared with the control groups.

\section{DISCUSSION}

Although Aristotle had already observed that alcohol-addicted women, gave birth to children that like their mothers, were taciturn and indolent (Burton, 1866); however, only folllowing isolated observations of Le Moine et al. in France in 1968 and Jones et al., in the United State in 1973, that the teratogenicity of maternal alcoholism was solidly established (Le Moine et al.).

The consumption of alcoholic beverages by sucklings began to attract the attention of 
Table IV. Mean values of nucleus-cytoplasm ratios, cytoplasm volumes $\left(\mathrm{mm}^{3}\right)$, cell volume (mm3), numerical cellular density $\left(\mathrm{n}^{\circ} / \mathrm{mm}^{3}\right)$ of osteocytes of control rats $(\mathrm{C})$ and ethanol treated rats $(\mathrm{T})$. Wilcoxon-Mann-Whitney test.

\begin{tabular}{lcccc}
\hline \multicolumn{1}{c}{ Parameter } & Control & Treated & $\mathbf{U}$ & $\mathbf{p}[\mathbf{U}]$ \\
\hline Nucleus-cytoplasm ratio & 0.0943 & 0.1341 & $12^{\text {ns }}$ & 0.500 \\
Cytoplasm volume & 1106.55 & 454.77 & $0^{*}$ & 0.004 \\
Cell volume & 1216.68 & 502.32 & $0^{*}$ & 0.004 \\
Numerical cell density & 839688.1 & 2667655.2 & $0^{*}$ & 0.004
\end{tabular}

Table V. Percent average values of the structure of the upper first molar alveolar bone of control $(\mathrm{C})$ and ethanol treated rats $(\mathrm{T})$ during lactation. Wilcoxon-MannWhitney test.

\begin{tabular}{lcccc}
\hline \multicolumn{1}{c}{ Parameter } & Control & Treated & $\mathbf{U}$ & $\mathbf{p}[\mathbf{U}]$ \\
\hline Osteocyte nucle us & 3.0 & 2.0 & $4^{* *}$ & 0.048 \\
Osteocyte cytoplasm & 12.3 & 3.9 & $0^{*}$ & 0.004 \\
Matrix & 54.0 & 38.0 & $0^{*}$ & 0.004 \\
Medulla & 31.6 & 56.1 & $0 *$ & 0.004 \\
\hline
\end{tabular}

researchers over the recent decades, with significant findings related to sucklings and milk-producers. Such beverages, considered by the U.S. Department of Health, Education and Welfare (HEW), as anaesthetic and sedative drugs, are transferred to mother milk following a consumption of 1g/kg/day (Abel, 1964, 1974, 1978; Abel \& Dintcheff, 1978).

Thus, the present work demonstrates, using histometry in a unprecedented manner, the alteration caused by ethanol through maternal milk, on the alveolar bone at th first molar level, in rat offspring.

Concerning mean body weights of the young animals, (20.20g) it was demonstrated that in those treated, it was reduced when compared to the controls $(\mathrm{a}<0.01)$.

This result agrees with that obtained by Abel, who in 1974, had observed that suckling, whose mother drank alcohol, showed significantly lower growth levels compared to controls, and by Collard \& Chen, 1973 (mentioned by Abel, 1974) who verified that injections of ethanol in milk- producing mice delayed growth of their young.

Oyama et al., (2000) observed that maternal ingestion of ethanol, affected offspring development in a dose-dependent way. At 10 or $20 \%$ in drinking water it caused a decrease of body weight, a result however not noted when $5 \%$ ethanol was tested.

Our stereological data confirm that osteocytes cell and cytoplasm volumes, were smaller in treated animals who besides, showed an increased number of osteocytes per $\mathrm{mm}^{3}$ of calcified matrix (Table IV).

By karyometry, it was possible to observe that osteocyte nuclei were smaller in the treated rat major, minor and medium volume, area, perimeter and V/A relation, but nuclear shape was not modified (Table II). In a similar way, osteoblast nuclei were smaller in the treated animals, with lower values for major, minor and medium diameters, volume, area, perimeter and V/A relation; shapes of the nuclei were flatter (Table I).

Regarding alveolar bone, trabeculae at the level of the upper first molar of treated rats showed to be more delicate and less calcified, with a more abundant medula.

A plausible explanation of these findings, based on two mechanisms of action of ethanol: a direct one on the tissues, or an indirect one, due to the poor nutrition afforded in these cases.

From the point of view of the direct action, many studies have demonstrated that ethanol or its metabolite acetaldehyde, alter protein synthesis, inhibiting its transport and secretion by the liver (Lieber, 1983, 1985). Other studies have indicated that these compounds act at the microtubule level (Matsuda et al., 1979; Baraona et al., 1984). This microtubule alteration is associated with the intracellular accumulation of secretory vesicles and with a general distension of the endoplasmic cisterns (Feldman \& Maurice, 1977). Although the liver is the major organ responsible for ethanol oxidation, many alterations produced by the ingestion of ethanol were observed in other tissues, for example, poor functioning of the cardiovascular system, alcoholic myopathy, etc. (Klatsky, 1982).

On the aspect of nutritional alteration, continuous ingestion of alcohol during lactation, alters the chemical composition of milk (Sanchis \& Guerri; Viñas et al.), resulting in the appearance of ethanol and acetaldehyde in milk (Guerri \& Sanchis, 1986), and exacerbating the effects of ethanol in the newborn (Guerri et al.). Jones \& Stewart (1984) observed a decreased gland weight, as sell as histological alterations of fat and epithelial cells of mammary tissue of rats receiving ethanol in their drinking water. Such 
structural alterations may contribute to the functional defects observed in mammary glands of animals treated by ethanol with ensuing jeopardy of the nutrition of the young.

Therefore, based on the presented results, it becomes possible to conclude that $20 \%$ ethanol in drinking water, administered to the lactating rat, evokes the following effects in the suckling: a) A significant decrease of body weight.

b) Alterations of the trabecule of the alveolar bone, observed stereologically, and expressed by few and little calcified trabeculae, with an abundant medula.

c) Less voluminous osteoblast and osteocyte nuclei, the former being flattened.

d) Osteocytes showing smaller cell and cytoplasm volume and a greater number of cells per $\mathrm{mm}^{3}$.

CURI, V.; AZOUBEL, R.; LOPES, R. A.; MARTINS, A. T.; DI MATTEO, M. A. S. \& KASSIS, E. N. Estudio histométrico del hueso alveolar en ratas sometidas a etanol durante la lactancia. Int. J. Morphol., 26(4):945-950, 2008.

RESUMEN: Considerando que la lactancia es un período importante y vulnerable, y que la exposición materna al alcohol durante esta fase puede provocar efectos adversos en las crías en desarrollo, el propósito del presente trabajo es evaluar histométricamente (mediante cariometría y estereología), el hueso alveolar a nivel del primer molar superior, de ratas lactantes sometidas a los efectos del etanol. Con esa finalidad utilizamos dos grupos, uno que recibió etanol al $20 \%$ en el bebedero, durante todo el período de lactancia (21días), y otro que recibió solo agua. En el $21^{\circ}$ día de lactancia, 5 ratas de cada grupo fueron aleatoriamente seleccionadas. Después de sacrificados, los animales fueron fijados en formol al 10\%. Las cabezas, separadas de los cuerpos, fueron incluidas en parafina, y cortadas seriadamente con $6 \mu \mathrm{m}$ de grosor, a partir de un plano frontal al nivel de los molares, y teñidas con hematoxilina y eosina. Basados en los resultados presentes, es posible concluir que el etanol al 20\% en el agua de beber, administrado a ratas lactantes, provoca los siguientes efectos: reducción significativa del peso corporal, alteraciones de las trabéculas del hueso alveolar, observadas estereológicamente, evidenciadas por trabéculas delicadas y poco calcificadas, con médula abundante, núcleos menores en osteoblastos y osteocitos y más achatados en los primeros, y con osteocitos de volúmenes citoplasmático y celular menor y densidad numérica mayor.

\section{PALABRAS CLAVE: Etanol; Hueso Alveolar; Lactato.}

\section{REFERENCES}

Abel, E. L. Alcohol ingestion in lactating rats: effects on mother and offspring. I. Arch Int. Pharmacodyn. Gent (Belgium), 210:121-7, 1974.

Abel, E. L. Effects of ethanol on pregnant rats and their offspring. Psychopharmacology, 57(1):5, 1978.

Abel, E. L. Fetal alcohol syndrome and fetal alcohol effects. New York, Plenum Press, 1964. pp.183-205.

Abel, E. L. \& Dintcheff, B. A. Effects of prenatal alcohol exposure on growth and development in rats. J. Pharmacol. Exp. Ther., 207(3):916-21, 1978.

Baraona, E.; Finkelman, F. \& Lieber, C. S. Reevaluation of the effects of alcohol comsumption on rat liver microtubules. Res. Commun. Chem. Phatol. Pharmacol., 44(2):265-78, 1984.

Burgos,G. P. A.; Bion, M. M. \& Campos, F. Lactação e álcool: Efeitos clínicos e nutricionais. ALAN, 54(1):25-35, 2004.

Burton, R. (Printed under “Democritus Jr."). The Anatomy of melancholy. London, Willian Tegg, 1866.

Chalkley, H. W. Metehod for the quantitative morphologic analysis of tissues. J. Natl. Cancer Just., 4:47-53, 1943.
Clarren, S. K. \& Smith, D. W. The fetal alcohol syndrome. $N$. Eng. J. Med., 298(19):1063-7, 1978.

DeBeukelaer, M. M.; Randall, C. L. \& Stroud, D. R. Renal abnormalities in a child with fetal alcohol syndrome. $J$. Pediatr., 91(5):759-60, 1977.

Delesse, M. A. Procédè méchanique pour déterminer la composition des roches. Annales des Mines, 13:379-88, 1848.

Do Carmo M. G. T.; Do Nascimento C. M. O.; Martin A. \& Herrera E. Ethanol intake during lactation impairs milk production in rats and affects growth and metabolism of suckling pups. Alcohol, 18(1):71-6, 1999.

Faustino, S. E. S. \& Stipp, A. C. M. Effects of chronic alcoholism and alcoholic detoxication on rat submandibular glands: morphometric study. J. Appl. Oral Sci., 11:21-6, 2003.

Feldman, G. \& Maurice, M. Morfological findings of liver protein synthesis and secretion. In Hopper, H.; Bianchi, L. \& Reutter, W. (Eds.). Membrane alterations as basis of liver injury. Lancaster, Med. Tech. Publ., 1977. pp. 61-76.

Goldstein, G. \& Arulanantham K. Neural tube defect and retal abnormalities in a child with fetal alcohol syndrome. $J$. Pediatr., 93(4):636-7, 1978. 
Grant, B. F. Prevalence and correlates of alcohol use and DSM-IV alcohol dependence in the United States: results of the National Longitudinal Alcohol Epidemiologic Survey. J. Stud. Alcohol, 58(5):464-73, 1997.

Guerri, C. \& Sanchis, R. Alcohol and acetaldehyde in rats milk following ethanol administration. Life Sci., 38:1543-56, 1986.

Guerri, C.; Esquifino, A.; Sanchis, R. \& Grisolia, S. Growth, enzymes and hormonal changes in offspring of alcohol-fed rats, in mechanisms of alcohol damage in utero. Ciba Foundation Symposium., 105:85-102, 1984.

Hanson, J. W.; Jones, K. L. \& Smith, D. W. Fetal alcohol syndrome. Experience with 41 patients. J. Am. Med. Assoc., 235(14):145860, 1976.

Hochgraf, P. B.; Zilberman, M. L. \& Andrade, A. G. Women alcoholics social, demographic and clinical characteristics in a Brazilian sample. Alcohol and Alcoholism., 30: 427-32, 1995.

Jones, K. L. \& Smith, D. W. The fetal alcohol syndrome. Teratology, 12(1):1-10, 1975.

Jones, K. L.; Smith D. W.; Ulleland, C. N. \& Streissguth, A. P. Pattern of malformations in offspring of chronic alcoholic mothers. Lancet, 1(7815):1267-71, 1973.

Jones, W. L. \& Stewart, D. B. Effects of orally-administered ethanol on mammary gland morphology and functional efficiency in lactating rats. Exp. Pathol., 25:205-13, 1984.

Klatsky, A. L. The relations of alcohol and the cardiovascular system. Апnи. Rev. Nutr., 2:51-71, 1982.

Le Moine, P.; Harousseau, H.; Borteyru, J. P. \& Menuet, J. C. Les enfants de parents alcooliques: Anomalies observées à propos de 127 cas. Quest. Méd., 25:476, 1968.

Lieber, C. S. Interactions of alcohol and nutrition. Introduction to a Symposium. Alcohol Clin. Exp. Res., 7(1):2-4, 1983.

Lieber, C. S. Metabolism of ethanol, metabolic effects and pathogenesis of injury. Acta Scand. (Suppl. 703):11, 1985.

Little, R. E.; Anderson, K. W.; Ervin, C. H.; Worthington-Roberts, B. \& Clarren, S. K. Maternal alcohol use during breast feeding and infant mental and motor development at one year. N. Engl. J. Med., 321:425-30, 1989.

Matsuda, Y.; Baraona, E.; Salaspuro, M. \& Lieber, C. S. Effects of ethanol on liver microtubules and Golgi apparatus. Possible role in altered hepatic secretion of plasma proteins. Lab. Invest., 41(5):455-63, 1979.

Mennella, J. A. \& Beauchamp, G. K. Beer breast feeding, and folklore. Dev. Psychobiol., 26:459-66, 1993.
Merz, W. A. Steekenmessung an gerichteten strukturen in mikroskop und Anwendung zur Bestimmung von oberflachen volumen relationen im knochengewebe. Mikroskopie, 22(5):132-42, 1967.

Oyama, L. M.; Couto, R. C.; Couto, G. E. C.; Dâmaso, A. R. \& Oller-do-Nascimento, C. M. Ethanol intake during lactation I. Effects on dams metabolism and pups' body weight gain. Alcohol., 21:195-200, 2000.

Peiffer, J.; Majewzki, F.; Fishbeck, H.; Bierich, J. R. \& Volk, B. Alcohol embryo and fetopathy. Neuropathology of 3 children and 3 fetuses. J. Neurol. Sci., 47:125-37, 1979.

Sala, M. A.; Komesu, M. C.; Lopes, R. A. \& Maia Campos, G. Karyometric study for basal cell carcinoma. Braz. Dent. J., 5(1):11-4, 1994.

Sala, M.; Lopes R. A. \& Matheus, M. Método morfológico para análisis cuantitativo de los tejidos. Determinacíon de los parámetros normales para el hepatocito de rata. Arch. de la Fac. Med. Zaragoza, 32(1):29-31, 1992.

Sanchis, R. \& Guerri, C. Chronic ethanol intake in lactating rats: Milk analysis. Comp. Biochem. Physiol., 85:107-10, 1986.

Tomkeieff, S. I. Linear intercepts, areas and volumes. Nature, 155(3923):24, 1945.

Veazie, M. A. \& Smith, G. S. Heavy drinking, alcohol dependence, and injuries at work among young workers in the United States labor force. Alcoholism. Clin. Exp. Res., 24(12):1811-9, 2000.

Vilaró S.; Viñas, O.; Remasar, X. \& Herrera, E. Effects of chronic ethanol consumption on lactational performance in rat: Mammary gland and milk composition and pups'growth and metabolism. Phamacol. Biochem. Behav., 27(2):333-9, 1987.

Viñas, O. Vilaró S.; Herrera, E. \& Remasar, X. Effects of chronic ethanol treatment on amino acid uptake and enzyme activities in the lactating rat mammary gland. Life Sci., 40:1745-9, 1987.

Weibel, E. R. Stereological principles for morphometry in electron microscopic cytology. Int. Rev. Cytol., 26:235-302, 1969.

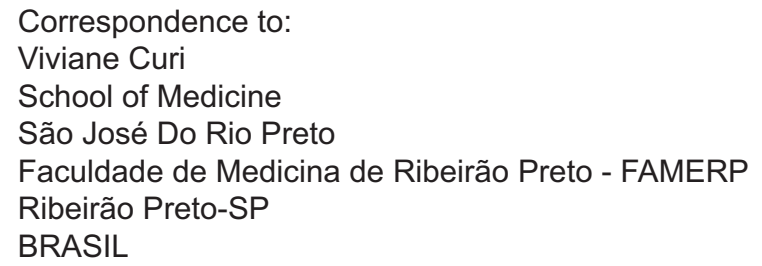

Received: 28-04-2008

Accepted: 15-04-2008 